\title{
Beneficial Effects of Probiotic Administration in Extremely Low Birthweight Infants: A Review
}

\author{
Steffi Beinlich ${ }^{1}$ and John V. Logomarsino ${ }^{2, *}$
}

${ }^{1}$ Pediatric and Neonatal Dietitian, Children's Hospital of Minnesota, 1811 Ulysses St NE Apt 11, Minneapolis, MN 55418, USA

${ }^{2}$ Nutrition and Dietetics, Central Michigan University, Department of Human Environmental Studies, 842 Maybank Loop, The Villages, FL 32162, USA

\begin{abstract}
The aim of this review was to evaluate the beneficial effects of probiotic supplementation on extremely low birthweight infants (birthweight $<1000 \mathrm{~g}$ ). Extremely low birthweight (ELBW) infants are the most vulnerable population in the neonatal intensive care unit (NICU). They are at the highest risk for necrotizing enterocolitis (NEC), sepsis, and inadequate nutrition due to their immature gastrointestinal (GI) function. Nutrition plays an important role in the future neurodevelopmental outcomes of these infants. Research methods for the review were conducted using PubMed and Cumulative Index to Nursing and Allied Health Literature (CINAHL). In total, eight research studies evaluated the effect of probiotic use in ELBW infants: three studies assessed GI colonization, five studies assessed enteral feeding and GI tolerance, one study assessed growth, five studies assessed NEC, five studies assessed sepsis, and two studies assessed length of hospital stay. This review found the use of probiotics improved Gl tolerance, weight gain and length of hospital stay in ELBW infants, but was unable to make conclusions on the effect of probiotic use on incidences of NEC and sepsis. More research is needed in ELBW infants before making probiotic supplementation a standard of care in this population.
\end{abstract}

Keywords: Bifidobacterium, extremely low birth weight infant, Lactobacillus, low birth weight infant, probiotics, very low birth weight infant.

\section{INTRODUCTION}

Extremely low birthweight (ELBW) infants are the highest risk group in the neonatal intensive care unit (NICU). Preliminary data from 2014 found that $8 \%$ of infants in the United States were born low birth weight (LBW), defined as a birthweight <2500 $\mathrm{g}$ [1]. Of those infants, the mortality rates have been the highest in infants with a birthweight of $500 \mathrm{~g}$ or less and has been found to decrease as birthweight increases [2]. Therefore, these ELBW infants, defined as a birthweight $<1000 \mathrm{~g}$, are at the highest risk, especially for gastrointestinal (GI) issues [3]. In addition, ELBW infants are also in greatest need of optimal nutrition to ensure adequate catch-up growth.

The two most common causes of morbidity and mortality in preterm infants are sepsis and necrotizing enterocolitis (NEC). These two conditions are responsible for up to $30 \%$ of deaths in this population and have substantial impact on long-term neurodevelopment [4]. NEC is a disease of the GI tract that is characterized by ischemic necrosis of the intestinal mucosa with associated inflammation and invasion of the enteric gas forming organisms [5]. The

${ }^{*}$ Address correspondence to this author at the Nutrition and Dietetics, Central Michigan University, Department of Human Environmental Studies, 842 Maybank Loop, The Villages, FL 32162, USA; Tel: (352) 430-5487;

E-mail: Jack.Logomarsino@cmich.edu mortality rate ranges from $15.9-42 \%$ of premature infants, and ELBW infants are at three times greater risk of developing NEC than very low birthweight infants (VLBW) [6]. Diagnosis of NEC is based on three stages. Stage 1 consists of nonspecific findings such as feeding intolerance or abdominal distention. Diagnosis of stage 2 requires radiographic findings of pneumatosis intestinalis, and stage 3 findings include perforated viscus with or without intestinal necrosis [5]. Although the causes of these disorders are multifaceted, it has been hypothesized that the immaturity of the gut and the lower diversity of beneficial bacteria can play a role in the immunoprotective functions of the Gl tract [7]. Occurrence of NEC or sepsis often requires enteral feedings to be held, which can result in the inadequate provision of nutrition and impact growth. Ensuring sufficient nutrition is one of the leading priorities for preterm infants. Failure to meet nutritional needs can have a negative impact on growth, neurodevelopment and morbidity [8].

Probiotics are suggested as a possible treatment option for improved $\mathrm{Gl}$ health in premature infants. Probiotics are live microorganisms that alter the microflora and provide a health benefit to the host when given in sufficient amounts [8-9]. Numerous studies have evaluated the effect of probiotics on VLBW infants. A Cochrane review found that probiotic 
use in preterm neonates significantly reduced the risk of stage 2 or greater NEC, but found no significant difference in rate of sepsis. This review did a subgroup comparison for ELBW infants. The authors of the review found no reduction in cases of severe stage 2 to 3 NEC, sepsis, or mortality, but were unable to come to any significant conclusions due to insufficient data regarding this population [10]. A systematic review of the benefits of probiotics on enteral nutrition in preterm infants found a significant decrease in the time it took to reach full enteral feeds in VLBW infants [11]. Although these reviews included studies with ELBW infants in their cohort, they did not look exclusively at the effect of probiotics on this population. This review aimed to evaluate the beneficial effects of probiotics in ELBW infants, as they are the highest risk patient group cared for in the neonatal intensive care unit (NICU).

\section{PROBIOTIC USE IN PREMATURE INFANTS}

Preterm infants' GI tracts have less diverse bacterial colonization due to their prematurity. Healthy, term, breastfed infants typically have high concentrations of the bacteria Lactobacillus and Bifidobacterium species in their gut [7,12-16]. These beneficial bacteria are often acquired during birth through the vaginal canal, but many ELBW infants are not exposed to this due to high rate of caesarean sections [7,17]. Preterm infants in the NICU are also at increased risk for colonization of the gut by pathogens from the hospital environment $[7,18]$. It has been hypothesized that the supplementation of probiotics can help to increase microbial diversity in the premature infant gut to make it more comparable to that of a healthy term infant [19]. Studies on premature infants have found that colonization of the $\mathrm{Gl}$ tract with probiotics can competitively inhibit bacterial pathogens and decrease the likelihood of bacterial translocation and infection [20]. Probiotics have also been hypothesized to help maintain the gut mucosal barrier to bacteria, increase immune response, and control intestinal inflammation $[8-9,21]$.

The goal for premature infants is to obtain a similar rate of growth and nutrient intake compared to a fetus of the same gestational age in utero [22-24]. It is often difficult for these premature infants to obtain adequate growth, since their intestinal function is less mature than their term counterparts [17]. Their immature gut can cause issues with feeding intolerance that delay the advancement of enteral feedings and makes it difficult to meet nutritional needs [23].
Inadequate nutrition in these high-risk infants can have adverse effects on long-term development, immune capability, resistance to infection, and ability to recover from chronic diseases of prematurity. Studies have shown that growth during hospitalization is positively associated with improved neurodevelopmental outcomes in ELBW infants [25]. To optimize their growth, many of these infants require supplemental parenteral nutrition, which brings additional risks such as sepsis, thrombosis and cholestasis [26]. By decreasing the time it takes to reach full enteral feedings, total parenteral nutrition could be discontinued earlier and prevent these potential complications.

ELBW infants are at an increased risk for Gl issues compared to their term counterparts. They are more likely to experience dysfunction of the epithelial barrier and dysmotility of the gut [27]. This can cause translocation of bacteria from the GI tract, which plays a role in the initiation of late-onset sepsis and NEC [17]. In addition to the increased risk of NEC and sepsis in ELBW infants, it is harder for them to meet their needs because in addition to increased metabolic demands, they have poor energy and protein stores [28].

To identify studies for this review, a literature search of PubMed and CINAHL was conducted on probiotic use in ELBW infants. Searches included combinations of the following medical subject heading terms and keywords: "extremely low birth weight infant," "very low birth weight infant," "low birth weight infant," "probiotics," "Bifidobacterium," and "Lactobacillus." For inclusion in this review, studies needed to include subjects who had a birthweight exclusively $<1000 \mathrm{~g}$ or stratify results into infants $<1000 \mathrm{~g}$. Studies also needed to have probiotic supplementation as an intervention. From these criteria, eight research papers published between 2006 and 2014 were identified and included in this review.

\section{Effect of Probiotic Supplements on GI Tract Colonization in ELBW Infants}

Three authors studied probiotic use and effect on GI tract colonization (Table 1). One study found the probiotic group had decreased stool fungal colonization compared to the control [21]. Similarly, another study evaluated the rate of GI fungal colonization. It found that the overall rate of $\mathrm{Gl}$ colonization of fungal species and high-grade colonization were reduced, but it was not statistically significant in the stratification of infants 
Table 1: Effect of Probiotic Use on Gastrointestinal Colonization in Extremely Low Birthweight Infants

\begin{tabular}{|c|c|c|c|c|}
\hline Reference & $\begin{array}{l}\text { Study type/ } \\
\text { number of } \\
\text { participants }\end{array}$ & $\begin{array}{c}\text { Probiotic dosage/ frequency/ } \\
\text { type of EN }\end{array}$ & Entry Criteria & Results \\
\hline $\begin{array}{c}\text { Manzoni } 2006 \\
{[3]}\end{array}$ & $\begin{array}{l}\text { Double-blinded, } \\
\text { PRCT } \\
\text { Infants }<1000 \text { g: pro } \\
\quad=12, C=8\end{array}$ & $\begin{array}{c}6 \times 10^{9} \text { CFU L. rhamnosus GG } \\
\text { Given once per day starting the } \\
\text { third DOL until } 6 \text { wk or DC } \\
\text { BM }\end{array}$ & $\begin{array}{l}\mathrm{BW}<1500 \mathrm{~g},>3 \mathrm{DOL}, \\
\text { stable oral feeding with } \\
\text { human milk before } \\
\text { randomization, no } \\
\text { baseline fungal } \\
\text { colonization, no } \\
\text { antifungal prophylaxis }\end{array}$ & $\begin{array}{c}\text { Incidence of GI colonization: } \\
\text { pro }=41.7 \% \text { vs. } 61.5 \% \text { ( } p=0.27), \\
\text { incidence of low-grade colonization: } \\
\text { pro= } 16.7 \% \text { vs. } C=30.8 \%(p=0.36), \\
\text { high-grade colonization: pro= } 25 \% \\
\text { vs. } 30.8 \%(p=0.55) \text {, incidence of } \\
\text { invasive fungal infection: pro }=16.7 \% \\
\text { vs. } C=15.4 \%(p=0.63) .\end{array}$ \\
\hline Roy 2014 [21] & $\begin{array}{l}\text { SC, double-blinded, } \\
\text { placebo, PRCT } \\
\text { Infants }<1000 \mathrm{~g} \text { : pro } \\
\quad=11, C=11\end{array}$ & $\begin{array}{c}1.5 \times 10^{9} \mathrm{CFU} L \text {. acidophilus, } B \text {. } \\
\text { infantis, B. lactis (increased to } 3 \\
\times 10^{9} \mathrm{CFU} \text { once EN reaches } 50- \\
60 \mathrm{ml} / \mathrm{kg} / \mathrm{day} \text { ) } \\
\text { Given pro daily from the first } 72 \\
\mathrm{~h} \text { for } 6 \text { wk or until DC } \\
\text { BM }\end{array}$ & $\begin{array}{l}\text { Stable feeding within } \\
72 \mathrm{~h} \text { of birth, <37 wk } \\
\mathrm{GA}, \mathrm{BW}<2500 \mathrm{~g}, \\
\text { adequate renal and } \\
\text { liver function, postnatal } \\
\text { age }<2 \mathrm{wk} \text {, no baseline } \\
\text { fungal colonization at } \\
\text { enrollment, no } \\
\text { antifungal prophylaxis }\end{array}$ & $\begin{array}{l}\text { Stool fungal colonization: pro }=3.06 \\
\pm 2.03 \times 10^{5} \text { CFU vs. } C=3 \pm 1.3 \times 10^{5} \\
\text { CFU ( } p=0.02) .\end{array}$ \\
\hline $\begin{array}{c}\text { Rougé } 2009 \\
\text { [26] }\end{array}$ & $\begin{array}{l}\text { MC, double-blinded, } \\
\text { PRCT } \\
\text { Infants } \leq 1000 \mathrm{~g} \text { (no } \\
\text { numbers given) }\end{array}$ & $\begin{array}{c}10^{8} \text { cells per unit } L \text {. rhamnosus } \\
G G \text { and } B \text {. longum } \\
\text { Given } 4 \text { times daily beginning } \\
\text { on the first day of enteral feeds } \\
\text { until DC } \\
\text { BM }\end{array}$ & $\begin{array}{l}<32 \text { wk GA, BW }<1500 \\
\text { g, postnatal age } \leq 2 w k \text {, } \\
\text { absence of any disease } \\
\text { other than those linked } \\
\text { to prematurity, start of } \\
\text { EN prior to inclusion }\end{array}$ & $\begin{array}{l}\text { Lower incidence of pro strain } \\
\text { colonization in infants } \leq 1000 \mathrm{~g} \text { than } \\
\text { those }>1000 \mathrm{gm}(p=0.02)\end{array}$ \\
\hline
\end{tabular}

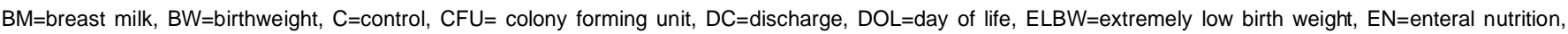
$\mathrm{GA}=$ gestational age, $\mathrm{Gl}=$ gastrointestinal, $\mathrm{h}=$ hour, $\mathrm{MC}=$ multicenter, $\mathrm{PRCT}=$ prospective randomized controlled trial, pro=probiotic, $\mathrm{SC}=\mathrm{single}$ center, wk=weeks.

$<1000 \mathrm{~g}$. There was also no difference in invasive fungal infection between the two groups [3]. An additional study found that Gl colonization of the probiotic strain provided was reduced with decreasing weight [26].

\section{Effect of Probiotic Supplements on Enteral Feeding and GI Tolerance in ELBW Infants}

Five studies evaluated the effect of probiotic supplementation on enteral feeding and GI tolerance (Table 2). To evaluate the benefits on enteral nutrition, many studies looked at the time it took to reach full enteral feedings and average feeding volume. Two studies found the probiotic group reached full feeds sooner and had an increased rate of feeding advancement $[9,21]$. In contrast, other studies found no difference in the time it took to reach full enteral feedings, the feeding ratio or feeding volume $[26,29]$. An additional study found no difference in average feeding volume in infants $<1000 \mathrm{~g}$ but did encounter an increase when stratified to infants with a birthweight between $751-1000 \mathrm{~g}$ [8].

One study evaluated the effect of probiotics on feeding intolerance. Feeding intolerance was defined as infants having gastric residuals greater than half of the provided feeding, abdominal distention, or bloody stools. The study found an improvement in feeding tolerance of the probiotic group compared to control [9].

Another trial investigated the role of probiotic use on gastric motility and intestinal blood flow. Pre and postprandial superior mesenteric artery blood flow velocity measurements were recorded in the second week of life after at least seven days of probiotic supplementation had been provided. Researchers found that the probiotic group had an increased postprandial time-averaged mean velocity, indicating improved intestinal motility. However, this did not decrease the time to full enteral feeding, as was expected [29].

\section{Effect of Probiotic Supplements on Growth in ELBW Infants}

One study evaluated the effect of probiotic use on weight gain and growth. It found that growth velocity was increased in the probiotic group compared to control in infants $<1000 \mathrm{~g}$. When stratified further by birthweight, there was also an increase in growth velocity and average weight gain per day in the probiotic group with a birthweight of 501-750 g. However, this improvement in growth was not statistically significant in the 751-1000 g group [8]. 
Table 2: Effect of Probiotic Use on Gastrointestinal Tolerance and Time to Full Enteral Feedings in Extremely Low Birthweight Infants

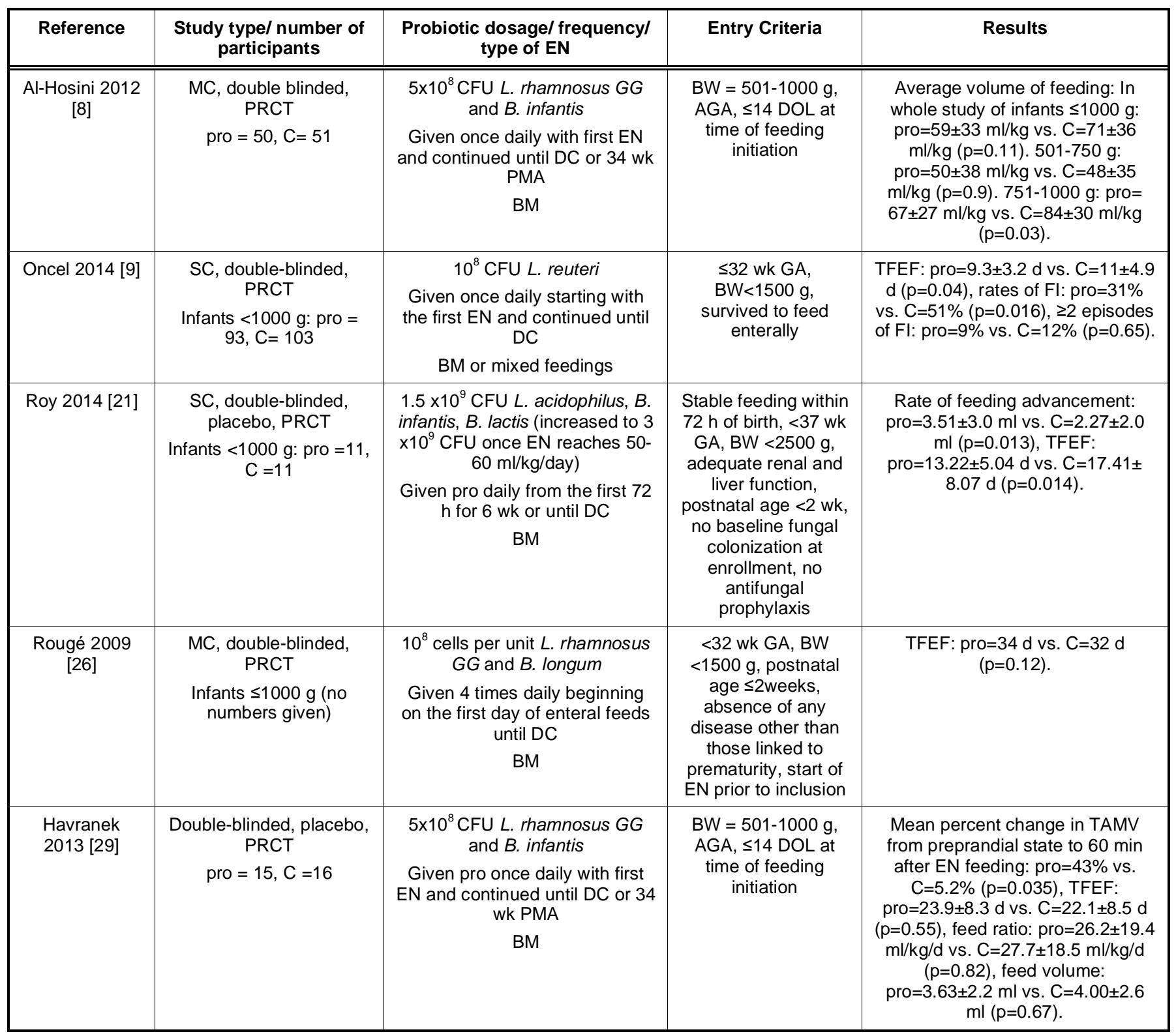

$\mathrm{AGA}=$ appropriate for gestational age, $\mathrm{BM}=$ breast milk, $\mathrm{BW}=$ birthweight, $\mathrm{C}=$ control, $\mathrm{CFU}=$ colony forming unit, $\mathrm{DC}=$ discharge, $\mathrm{DOL}=\mathrm{day}$ of life, $\mathrm{EN}=\mathrm{enteral}$ nutrition, $\mathrm{ELBW}=$ extremely low birth weight, $\mathrm{Fl}=$ feeding intolerance, $\mathrm{GA}=$ gestational age, $\mathrm{Gl}=$ gastrointestinal, $\mathrm{h}=\mathrm{hours}$, $\mathrm{SC}=\mathrm{single}$ center, $\mathrm{PMA}=\mathrm{postmenstrual}$ age, $\mathrm{PRCT}=$ prospective randomized controlled trial, pro=probiotic, TAMV=time-averaged mean velocity, TFEF=time to full enteral feedings, wk=weeks.

\section{Effect of Probiotic Supplements on Necrotizing Enterocolitis in ELBW Infants}

Five studies evaluated the effect of probiotics on NEC in ELBW infants (Table 3). A retrospective study compared the incidence of NEC in infants before and after the introduction of prophylactic use of probiotics. They found a decreased rate of all stages of NEC and NEC stage 2 after the introduction of prophylactic probiotic use [30]. Another study found a decreased incidence of death or NEC $\geq$ stage 2 in infants weighing $500-750 \mathrm{~g}$, but not for infants weighing 751-1000 g [31].
Other studies found no significant difference between probiotic and control in incidence of NEC [8-9,21], NEC $\geq 2$ stage 2 [9,31], or death attributable to NEC [9].

\section{Effect of Probiotic Supplements on Rates of Sepsis and Infection in ELBW Infants}

Six studies investigated rates of sepsis and infection (Table 4). One study found that sepsis occurred more frequently in the probiotic group, but there was no difference in Gram-positive or negative sepsis between the two groups [31]. Another study found a reduced rate of Candida infection and total fungal infection in 
Table 3: Effect of Probiotic Use on Necrotizing Enterocolitis in Extremely Low Birthweight Infants

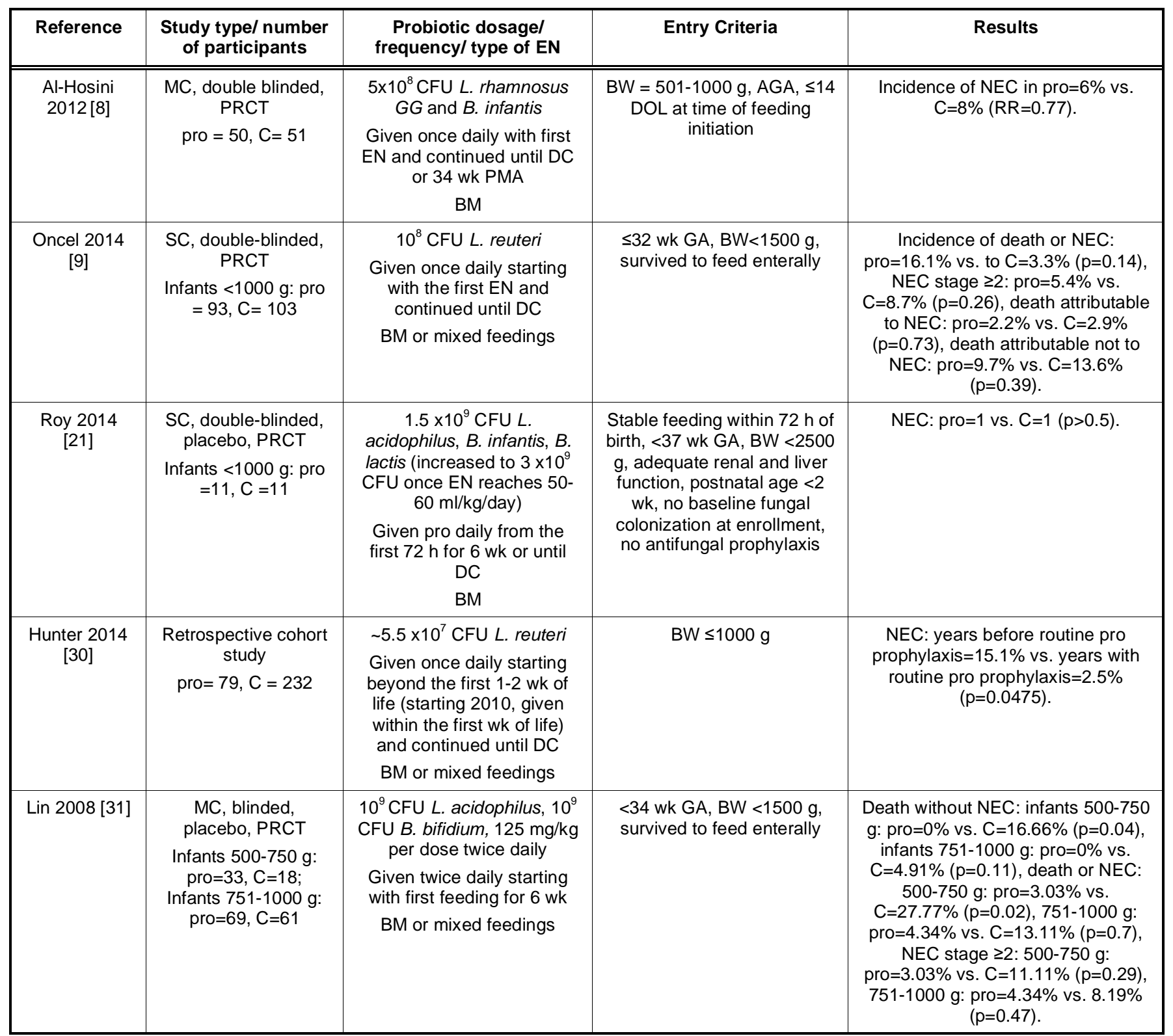

$\mathrm{BM}=$ breast milk, BW=birthweight, $\mathrm{C}=$ control, $\mathrm{CFU}=$ colony forming units, $\mathrm{DC}=$ discharge, $\mathrm{DOL}=$ day of life, $\mathrm{EN}=$ =enteral nutrition, ELBW=extremely low birthweight, $\mathrm{MC}=$ multicenter, $\mathrm{NEC}=$ necrotizing enterocolitis, $\mathrm{PMA}=$ postmenstrual age, $\mathrm{PRCT}=$ prospective randomized controlled trial, pro=probiotic, $\mathrm{SC}=$ single center, wk=weeks.

the probiotic group [21]. In contrast, one study found a decreased incidence of culture-proven sepsis in the group that was given probiotics [9]. Other studies found no difference in the incidence of sepsis $[8,26]$, or culture-positive bacterial or fungal infection [30].

\section{Effect of Probiotic Supplements on Length of Hospital Stay in ELBW Infants}

Two studies evaluated the effect of probiotic use on length of hospital stay. Both studies found that infants' length of time in the hospital decreased when they were given probiotic supplements. The length of time in the hospital was decreased by more than five days in one study [21], and more than ten days in the other [9].

\section{DISCUSSION}

This review shows mixed results on the benefit of probiotic use on Gl colonization and time to full enteral feedings. One study found that there was a decreased colonization of fungal species with the use of probiotics [21]. This suggests that the probiotics were able to compete with the harmful bacteria and reduce development of infection. This same study found an improvement in time to full enteral feedings, which is in 
Table 4: Effect of Probiotic Use on Sepsis and Infection in Extremely Low Birthweight Infants

\begin{tabular}{|c|c|c|c|c|}
\hline Reference & $\begin{array}{l}\text { Study type/ } \\
\text { number of } \\
\text { participants }\end{array}$ & $\begin{array}{l}\text { Probiotic dosage/ frequency/ type of } \\
\text { EN }\end{array}$ & Entry Criteria & Results \\
\hline $\begin{array}{l}\text { Al-Hosini } \\
2012[8]\end{array}$ & $\begin{array}{c}\text { MC, double } \\
\text { blinded, } P R C T \\
\text { pro }=50, C=51\end{array}$ & 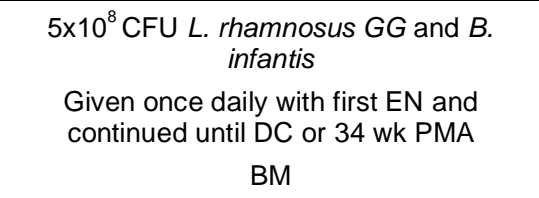 & $\begin{array}{l}\mathrm{BW}=501-1000 \mathrm{~g}, \mathrm{AGA} \\
\quad \leq 14 \mathrm{DOL} \text { at time of } \\
\text { feeding initiation }\end{array}$ & $\begin{array}{c}\text { Bacterial or fungal sepsis: } \\
\text { pro }=26 \% \text { vs. } \mathrm{C}=31 \% \\
(\mathrm{RR}=0.83), \text { any bacterial } \\
\text { sepsis: pro }=22 \% \text { vs. } \mathrm{C}=31 \% \\
\text { (RR }=0.70) .\end{array}$ \\
\hline $\begin{array}{c}\text { Oncel } \\
2014[9]\end{array}$ & $\begin{array}{c}\text { SC, double- } \\
\text { blinded, PRCT } \\
\text { Infants }<1000 \mathrm{~g}: \\
\text { pro }=93, \mathrm{C}=103\end{array}$ & $\begin{array}{l}10^{8} \text { CFU L. reuteri } \\
\text { Given once daily starting with the first EN } \\
\text { and continued until DC } \\
\text { BM or mixed feedings }\end{array}$ & $\begin{array}{l}\leq 32 \text { wk } \mathrm{GA}, \mathrm{BW}<1500 \mathrm{~g} \\
\text { survived to feed enterally }\end{array}$ & $\begin{array}{l}\text { Incidence of culture proven } \\
\text { sepsis: pro=6.5\% vs. } 18.4 \% \\
(p=0.01)\end{array}$ \\
\hline $\begin{array}{c}\text { Roy } 2014 \\
{[21]}\end{array}$ & $\begin{array}{l}\text { SC, double- } \\
\text { blinded, placebo, } \\
\text { PRCT } \\
\text { Infants }<1000 \mathrm{~g} \text { : } \\
\text { pro }=11, \mathrm{C}=11\end{array}$ & $\begin{array}{c}1.5 \times 10^{9} \mathrm{CFU} \text { L. acidophilus, } B \text {. infantis, } \\
\text { B. lactis (increased to } 3 \times 10^{9} \mathrm{CFU} \text { once } \\
\text { EN reaches } 50-60 \mathrm{ml} / \mathrm{kg} / \text { day) } \\
\text { Given pro daily from the first } 72 \mathrm{~h} \text { for } 6 \mathrm{wk} \\
\text { or until DC } \\
\text { BM }\end{array}$ & $\begin{array}{l}\text { Stable feeding within } 72 \mathrm{~h} \\
\text { of birth, }<37 \text { wk GA, BW } \\
<2500 \mathrm{~g} \text {, adequate renal } \\
\text { and liver function, } \\
\text { postnatal age }<2 \mathrm{wk} \text {, no } \\
\text { baseline fungal } \\
\text { colonization at enrollment, } \\
\text { no antifungal prophylaxis }\end{array}$ & $\begin{array}{l}\text { Candida infection: pro }=1 \text { vs. } \\
C=3(p=0.001) \text {, no fungal } \\
\text { infection: pro }=6 \text { vs. } C=2 \\
(p=0.001)\end{array}$ \\
\hline $\begin{array}{l}\text { Rougé } \\
2014 \text { [26] }\end{array}$ & $\begin{array}{l}\text { MC, double- } \\
\text { blinded, PRCT } \\
\text { Infants } \leq 1000 \mathrm{~g} \text { (no } \\
\text { numbers given) }\end{array}$ & $\begin{array}{l}10^{8} \text { cells per unit } L \text {. rhamnosus } G G \text { and } \\
B \text {. longum } \\
\text { Given } 4 \text { times daily beginning on the first } \\
\text { day of enteral feeds until DC } \\
\text { BM }\end{array}$ & $\begin{array}{l}<32 \text { wk GA, BW }<1500 \mathrm{~g}, \\
\text { postnatal age } \leq 2 \text { weeks, } \\
\text { absence of any disease } \\
\text { other than those linked to } \\
\text { prematurity, start of EN } \\
\text { prior to inclusion }\end{array}$ & $\begin{array}{l}\text { Nosocomial infection: } \\
\text { pro }=75 \% \text { vs. } C=64 \% \\
\qquad(p=0.51)\end{array}$ \\
\hline $\begin{array}{l}\text { Hunter } \\
2014[30]\end{array}$ & $\begin{array}{l}\text { Retrospective } \\
\text { cohort study } \\
\text { pro }=79, \mathrm{C}=232\end{array}$ & $\begin{array}{l}\sim 5.5 \times 10^{7} \text { CFU L. reuteri } \\
\text { Given once daily starting beyond the first } \\
1-2 \text { wk of life (starting } 2010 \text {, given within } \\
\text { the first wk of life) and continued until DC } \\
\text { BM or mixed feedings }\end{array}$ & $\mathrm{BW} \leq 1000 \mathrm{~g}$ & $\begin{array}{l}\text { Late onset gram-negative } \\
\text { bacterial or fungal infection: } \\
\text { years before routine pro } \\
\text { prophylaxis }=31 \% \text { vs. years } \\
\text { with routine pro } \\
\text { prophylaxis }=22.8 \% \\
(\mathrm{p}=0.1112)\end{array}$ \\
\hline $\begin{array}{l}\operatorname{Lin} 2008 \\
\quad[31]\end{array}$ & $\begin{array}{c}\text { MC, blinded, } \\
\text { placebo, PRCT } \\
\text { Infants } 500-750 \mathrm{~g}: \\
\text { pro }=33, \mathrm{C}=18 ; \\
\text { Infants } 751-1000 \mathrm{~g} \text { : } \\
\text { pro }=69, \mathrm{C}=61\end{array}$ & $\begin{array}{c}10^{9} \mathrm{CFU} \text { L. acidophilus, } 10^{9} \mathrm{CFU} B \text {. } \\
\text { bifidium, } 125 \mathrm{mg} / \mathrm{kg} \text { per dose twice daily } \\
\text { Given twice daily starting with first feeding } \\
\text { for } 6 \mathrm{wk} \\
\text { BM or mixed feedings }\end{array}$ & $\begin{array}{l}<34 \text { wk GA, BW }<1500 \mathrm{~g}, \\
\text { survived to feed enterally }\end{array}$ & $\begin{array}{c}\text { Gram-positive sepsis: } 500- \\
750 \text { g: pro=27.3\% vs. } \\
C=5.6 \%(p=0.08), 751-1000 \\
\text { g: pro=11.6\% vs. } C=14.8 \% \\
\text { ( }=0.59), \text { gram-negative } \\
\text { sepsis: } 500-750 \text { g: } p r 0=9.1 \% \\
\text { vs. } 0 \%(p=0.54), 751-1000 \mathrm{~g}: \\
\text { pro=13.0\% vs. } 6.6 \% \\
(p=0.22) .\end{array}$ \\
\hline
\end{tabular}

$\mathrm{AGA}=$ appropriate for gestational age, $\mathrm{BM}=$ breast milk, $\mathrm{BW}=$ birthweight, $\mathrm{C}=$ control, $\mathrm{CFU}=$ colony forming units, $\mathrm{DC}=$ discharge, $\mathrm{DOL}=\mathrm{day}$ of life, $\mathrm{EN}=\mathrm{enteral}$ nutrition, ELBW=extremely low birthweight, $\mathrm{GA}=$ gestational age, $\mathrm{h}=$ hours, $\mathrm{MC}=$ multicenter, $\mathrm{PMA}=$ postmenstrual age, $\mathrm{PRCT}=$ prospective randomized controlled trial, pro=probiotic, $\mathrm{SC}=$ single center, $\mathrm{wk}=$ weeks

agreement with numerous studies on VLBW infants $[4,17,20,32-33]$. An additional study found that probiotic supplementation improved GI tolerance and time to full enteral feeding, suggesting that probiotics may improve intestinal motility, feeding tolerance, and assist in reaching full enteral feedings sooner [9]. Comparably, another study found improved intestinal motility, but this did not correlate with an improvement in time to full enteral feedings [29]. In contrast, one study found GI colonization of beneficial bacteria was improved in infants $<1500 \mathrm{~g}$, but the effect was reduced as weight decreased. Consequently, these ELBW infants failed to have improvement in time to full enteral feedings. The authors noted that these results may also be related to the increased use of antibiotics and increased frequency of held feedings in these ELBW infants, making it more unlikely for colonization [26].

Multiple meta-analyses have found a significant reduction in NEC with use of probiotics in VLBW infants. Due to the low number of ELBW infants included in these meta-analyses, the researchers were unable to detect a significant difference in those using probiotics [10,34]. The risk of NEC was inversely associated with birthweight, indicating that ELBW infants were the highest risk group. This review found 
mixed results on the effect of probiotic use on NEC in ELBW infants. Two studies did find a decrease in the incidence of NEC $[30,31]$. Another study found significance for only the infants with a birthweight between $500-750 \mathrm{~g}$. Of note, this study failed to stratify based on birthweight during randomization, which makes the results more difficult to translate due to type II error [31].

This review found varied results on probiotics reducing the incidence of sepsis and infection. The meta-analyses on VLBW infants found a slight positive effect on incidence of sepsis but did not reach statistical significance [10,34]. There was one study in this review that found a decrease in culture-positive sepsis [9]. Three others found no difference [8,26,31], and the remaining study found an increased rate of sepsis in those receiving probiotics [9]. In addition, multiple case studies have found associations between probiotic use and sepsis in VLBW and ELBW infants [35-37]. This suggests that probiotics likely do not decrease the incidence of sepsis, but these few cases do not necessarily indicate that they are the cause.

It is difficult to determine the effect of probiotic use on growth in ELBW infants. There was only one study that reported results on growth and found positive effects [9]. This is in agreement with a previous study in VLBW infants [12]. There were also minimal studies that reported on length of hospital stay in this review. Two studies did find a decrease in length of hospital stay with the use of probiotics $[9,21]$. As expected, both of these studies found that infants reached full enteral feedings sooner.

This review suggests that probiotic supplementation may have a positive effect on the health and wellness of ELBW infants. Probiotics have been found to improve GI tolerance and motility, which is often an obstacle in providing adequate nutrition in ELBW infants. Interestingly, not all studies found an improvement in time to full enteral feedings, which would be expected with improvement Gl function. This may be due to differing practices of facilities on how long enteral feedings are held for procedures or frequency of antibiotic use. Of those studies with reduced time to enteral feedings, there was also found to be improved weight gain, and decreased length of hospital stay. Due to the mixed results, it is difficult to make conclusions regarding the effect of probiotic use on NEC in ELBW infants. The risk of sepsis also needs to be considered in this immunocompromised population. Since there is convincing evidence of the benefit of probiotics on NEC in VLBW infants, it is reasonable to assume that there may be benefits for ELBW infants. More studies are needed on exclusively ELBW infants to weigh out the risks and benefits in this population.

In order to accurately interpret these results, there are strengths and limitations to this review that must be considered. One strength is that seven of the eight studies included were randomized controlled trials (RCT). All of these RCT were blinded and used a placebo for comparison. In addition, a majority of the studies followed a feeding protocol to ensure that feedings were started and advanced in the same manner to eliminate any inconsistency. A major weakness of this review is the variation in type, dosage, initiation and duration of probiotics use, as well as the use of single-strain versus multiple-strains supplement. Another important limitation is the lack of studies that included only ELBW infants. Only three of the eight studies evaluated included infants $<1000 \mathrm{~g}$. The other five studies stratified the study infants into the $<1000 \mathrm{~g}$ category, creating small sample sizes of these infants. The studies that stratified their results into $<1000 \mathrm{~g}$ did not evaluate all outcomes that were assessed in the full study.

The conclusions drawn here suggest several areas for future research. While it may be assumed that results in VLBW infants can be extrapolated to ELBW infants, they have unique barriers to overcome. ELBW infants begin with lower nutrient stores and are more likely to have medical conditions that are given priority over delivering adequate nutrition. Since they are the most vulnerable population and at highest risk of NEC, it would make finding prevention strategies in this group even more imperative. More research is needed to determine an appropriate probiotic strain to be sure it can be produced by a reputable source in a safe manner. Further studies should also measure long term outcomes in these infants to provide a full picture of the benefits.

\section{CONCLUSION}

Although there have been numerous research studies on the benefits of probiotic use in VLBW infants, data are insufficient in the ELBW population. This vulnerable group could benefit the most from normalizing gut microbiota, advancing enteral feedings more quickly, and the prevention of devastating diseases such as NEC. This review found that probiotics may provide a benefit on feeding tolerance 
and GI motility. Even the slightest improvement in GI tolerance can promote positive nutritional outcomes and effect long-term development in ELBW infants. It is difficult to determine the effectiveness of probiotic use on growth and length of hospital stay due to the limited studies available on ELBW infants. Although there were some positive results in the use of probiotics, more research is needed in these ELBW infants before conclusions can be reached and it is made a standard of care in this population.

\section{REFERENCES}

[1] Hamilton BE, Martin JA, Osterman MJ, Curtin SC. Births: Final data for 2014. Natl Vital Stat Rep 2015; 64(12): 1-64.

[2] MacDorman MF, Gregory EC. Fetal and perinatal mortality: United States, 2013. Natl Vital Stat Rep 2015; 64(8): 1-24.

[3] Manzoni $\mathrm{P}$, Mostert $\mathrm{M}$, Leonessa $\mathrm{ML}$, et al. Oral supplementation with Lactobacillus casei subspecies rhamnosus prevents enteric colonization by Candida species in preterm neonates: a randomized study. Clin Infect Dis [Internet]. 2006 [cited 2016 April 2]; 42(12): 1735-42. http://dx.doi.org/10.1086/504324

[4] Härtel C, Pagel J, Rupp J, et al. Prophylactic use of Lactobacillus acidophilus/Bifidobacterium infantis probiotics and outcome in very low birth weight infants. J Pediatr [Internet]. 2014 [cited 2016 April 2];165(2): 285-289.e281. http://dx.doi.org/10.1016/j.jpeds.2014.04.029

[5] Neu J, Walker WA. Necrotizing enterocolitis. N Engl J Med [Internet]. 2011 [cited 2016 April 2]; 364(3): 255-64. http://dx.doi.org/10.1056/NEJMra1005408

[6] Fitzgibbons SC, Ching Y, Yu D, et al. Mortality of necrotizing enterocolitis expressed by birth weight categories. J Pediatr Surg [Internet]. 2009 [cited 2016 April 2]; 44(6): 1072-5; discussion 5-6.

http://dx.doi.org/10.1016/j.jpedsurg.2009.02.013

[7] Garland SM, Tobin JM, Pirotta M, et al. The ProPrems trial: investigating the effects of probiotics on late onset sepsis in very preterm infants. BMC Infect Dis. [Internet] 2011 [cited 2016 April 2]; 11: 210.

http://dx.doi.org/10.1186/1471-2334-11-210

[8] Al-Hosni $M$, Duenas $M$, Hawk $M$, et al. Probioticssupplemented feeding in extremely low-birth-weight infants. J Perinatol. [Internet] 2012 [cited 2016 April 2]; 32(4): 253-9. http://dx.doi.org/10.1038/jp.2011.51

[9] Oncel MY, Sari FN, Arayici S, et al. Lactobacillus Reuteri for the prevention of necrotising enterocolitis in very low birthweight infants: a randomised controlled trial. Arch Dis Child Fetal Neonatal Ed. [Internet] 2014 [cited 2016 April 2]; 99(2): F110-5. http://dx.doi.org/10.1136/archdischild-2013-304745

[10] AlFaleh K, Anabrees J. Probiotics for prevention of necrotizing enterocolitis in preterm infants. Cochrane Database Syst Rev. [Internet] 2014 [cited 2016 April 2]; 4: CD005496. http://dx.doi.org/10.1002/ebch.1976

[11] Athalye-Jape G, Deshpande G, Rao S, Patole S. Benefits of probiotics on enteral nutrition in preterm neonates: a systematic review. Am J Clin Nutr. [Internet] 2014 [cited 2016 April 2]; 100(6): 1508-19. http://dx.doi.org/10.3945/ajcn.114.092551

[12] Bin-Nun A, Bromiker R, Wilschanski M, et al. Oral probiotics prevent necrotizing enterocolitis in very low birth weight neonates. J Pediatr. [Internet] 2005 [cited 2016 April 2]; 147(2): 192-6.

http://dx.doi.org/10.1016/i.jpeds.2005.03.054
[13] Chrzanowska-Liszewska D, Seliga-Siwecka J, Kornacka MK. The effect of Lactobacillus rhamnosus GG supplemented enteral feeding on the microbiotic flora of preterm infantsdouble blinded randomized control trial. Early Hum Dev. [Internet] 2012 [cited 2016 April 2]; 88(1): 57-60. http://dx.doi.org/10.1016/j.earlhumdev.2011.07.002

[14] Magne F, Abély M, Boyer F, Morville P, Pochart P, Suau A. Low species diversity and high interindividual variability in faeces of preterm infants as revealed by sequences of $16 \mathrm{~S}$ rRNA genes and PCR-temporal temperature gradient gel electrophoresis profiles. FEMS Microbiol Ecol. [Internet] 2006 [cited 2016 April 2]; 57(1): 128-38. http://dx.doi.org/10.1111/j.1574-6941.2006.00097.x

[15] Mshvildadze M, Neu J, Shuster J, Theriaque D, Li N, Mai V. Intestinal microbial ecology in premature infants assessed with non-culture-based techniques. J Pediatr. [Internet] 2010 [cited 2016 April 2]; 156(1): 20-5.

http://dx.doi.org/10.1016/j.jpeds.2009.06.063

[16] Schwiertz A, Gruhl B, Löbnitz M, Michel P, Radke M, Blaut $M$. Development of the intestinal bacterial composition in hospitalized preterm infants in comparison with breast-fed, full-term infants. Pediatr Res. [Internet] 2003 [cited 2016 April 2]; 54(3): 393-9.

http://dx.doi.org/10.1203/01.PDR.0000078274.74607.7A

[17] Totsu S, Yamasaki C, Terahara M, Uchiyama A, Kusuda S, Japan PSGi. Bifidobacterium and enteral feeding in preterm infants: cluster-randomized trial. Pediatr Int. [Internet] 2014 [cited 2016 April 2]; 56(5): 714-9. http://dx.doi.org/10.1111/ped.12330

[18] Rojas MA, Lozano JM, Rojas MX, et al. Prophylactic probiotics to prevent death and nosocomial infection in preterm infants. Pediatrics. [Internet] 2012 [cited 2016 April 2]; 130(5): e1113-20.

http://dx.doi.org/10.1542/peds.2011-3584

[19] Neu J, Caicedo R. Probiotics: protecting the intestinal ecosystem? J Pediatr. [Internet] 2005 [cited 2016 April 2]; 147(2): 143-6. http://dx.doi.org/10.1016/j.jpeds.2005.05.033

[20] Dilli D, Aydin B, Fettah ND, et al. The propre-save study: effects of probiotics and prebiotics alone or combined on necrotizing enterocolitis in very low birth weight infants. J Pediatr. [Internet] 2015 [cited 2016 April 2]; 166(3): 54551.e1.

\section{http://dx.doi.org/10.1016/j.jpeds.2014.12.004}

[21] Roy A, Chaudhuri J, Sarkar D, Ghosh P, Chakraborty S. Role of Enteric Supplementation of Probiotics on Late-onset Sepsis by Candida species in Preterm Low Birth Weight Neonates: A Randomized, Double Blind, Placebo-controlled Trial. N Am J Med Sci [Internet]. 2014 [cited 2016 April 2]; 6(1): 50-7. http://dx.doi.org/10.4103/1947-2714.125870

[22] Dejhalla M, Lahage N, Parvez B, Brumberg HL, La Gamma EF. Early Postnatal Growth in a Subset of Convalescing Extremely-Low-Birth-Weight Neonates: Approximating the "Index Fetus" Ex Utero. J Pediatr Gastroenterol Nutr. [Internet] 2015 [cited 2016 April 2]; 61(3): 361-6. http://dx.doi.org/10.1097/MPG.0000000000000750

[23] Peiler A, Woelfle J, Stutte S, Schreiner F, Bartmann P Gohlke B. Postnatal nutrition in extremely low birth weight infants and its impact on growth until the age of 6 years. Acta Paediatr. [Internet] 2014 [cited 2016 April 2]; 103(2): e61-8. http://dx.doi.org/10.1111/apa.12469

[24] Martin CR, Brown YF, Ehrenkranz RA, et al. Nutritional practices and growth velocity in the first month of life in extremely premature infants. Pediatrics. [Internet] 2009 [cited 2016 April 2]; 124(2): 649-57. http://dx.doi.org/10.1542/peds.2008-3258

[25] Ehrenkranz RA, Dusick AM, Vohr BR, Wright LL, Wrage LA, Poole WK. Growth in the neonatal intensive care unit influences neurodevelopmental and growth outcomes of 
extremely low birth weight infants. Pediatrics. [Internet] 2006 [cited 2016 April 2]; 117(4): 1253-61.

http://dx.doi.org/10.1542/peds.2005-1368

[26] Rougé C, Piloquet $\mathrm{H}$, Butel MJ, et al. Oral supplementation with probiotics in very-low-birth-weight preterm infants: a randomized, double-blind, placebo-controlled trial. Am J Clin Nutr. [Internet] 2009 [cited 2016 April 2]; 89(6): 1828-35. http://dx.doi.org/10.3945/ajcn.2008.26919

[27] Neu J. Necrotizing enterocolitis: the mystery goes on. Neonatology. [Internet] 2014 [cited 2016 April 2]; 106(4): 289-95.

http://dx.doi.org/10.1159/000365130

[28] Dinerstein A, Nieto RM, Solana CL, Perez GP, Otheguy LE, Larguia AM. Early and aggressive nutritional strategy (parenteral and enteral) decreases postnatal growth failure in very low birth weight infants. J Perinatol. [Internet] 2006 [cited 2016 April 2]; 26(7): 436-42. http://dx.doi.org/10.1038/sj.jp.7211539

[29] Havranek T, Al-Hosni M, Armbrecht E. Probiotics supplementation increases intestinal blood flow velocity in extremely low birth weight preterm infants. J Perinatol. [Internet] 2013 [cited 2016 April 2]; 33(1) :40-4. http://dx.doi.org/10.1038/jp.2012.37

[30] Hunter C, Dimaguila MA, Gal P, et al. Effect of routine probiotic, Lactobacillus reuteri DSM 17938, use on rates of necrotizing enterocolitis in neonates with birthweight $<1000$ grams: a sequential analysis. BMC Pediatr. [Internet] 2012 [cited 2016 April 2]; 12: 142. http://dx.doi.org/10.1186/1471-2431-12-142

[31] Lin $\mathrm{HC}$, Hsu $\mathrm{CH}$, Chen $\mathrm{HL}$, et al. Oral probiotics prevent necrotizing enterocolitis in very low birth weight preterm infants: a multicenter, randomized, controlled trial. Pediatrics. [Internet] 2008 [cited 2016 April 2]; 122(4): 693-700. http://dx.doi.org/10.1542/peds.2007-3007
[32]

Samanta M, Sarkar M, Ghosh P, Ghosh J, Sinha M, Chatterjee S. Prophylactic probiotics for prevention of necrotizing enterocolitis in very low birth weight newborns. J Trop Pediatr. [Internet] 2009 [cited 2016 April 2]; 55(2): 12831. http://dx.doi.org/10.1093/tropej/fmn091

[33] Braga TD, da Silva GA, de Lira PI, de Carvalho Lima M. Efficacy of Bifidobacterium breve and Lactobacillus casei oral supplementation on necrotizing enterocolitis in very-low-birthweight preterm infants: a double-blind, randomized, controlled trial. Am J Clin Nutr. [Internet] 2011 [cited 2016 April 2]; 93(1): 81-6. http://dx.doi.org/10.3945/ajcn.2010.29799

[34] Lau CS, Chamberlain RS. Probiotic administration can prevent necrotizing enterocolitis in preterm infants: A metaanalysis. J Pediatr Surg. [Internet] 2015 [cited 2016 April 2]; 50(8): 1405-12.

http://dx.doi.org/10.1016/i.jpedsurg.2015.05.008

[35] Jenke A, Ruf EM, Hoppe T, Heldmann M, Wirth S. Bifidobacterium septicaemia in an extremely low-birthweight infant under probiotic therapy. Arch Dis Child Fetal Neonatal Ed. [Internet] 2012 [cited 2016 April 2]; 97(3): F217-8. http://dx.doi.org/10.1136/archdischild-2011-300838

[36] Salminen MK, Rautelin H, Tynkkynen S, et al. Lactobacillus bacteremia, clinical significance, and patient outcome, with special focus on probiotic L. rhamnosus GG. Clin Infect Dis. [Internet] 2004 [cited 2016 April 2]; 38(1): 62-9. http://dx.doi.org/10.1086/380455

[37] Zbinden A, Zbinden R, Berger C, Arlettaz R. Case series of Bifidobacterium longum bacteremia in three preterm infants on probiotic therapy. onatology. [Internet] 2015 [cited 2016 April 2]; 107(1): 56-59. http://dx.doi.org/10.1159/000367985 